the first scientific adviser to the National Gallery, and from very small beginnings he has built up a department which has made notable contributions in its special field. Mr. Rawlins was responsible for the arrangements for the transport of the pictures from the Gallery at the outbreak of war and for providing them with a place of refuge in a quarry in Wales where they were stored under carefully controlled conditions of temperature and humidity. He was successful in securing a grant from the Nuffield Foundation for scholarships at the Gallery. The scholarships proved of such value that the Treasury has assumed responsibility for these posts. The research that has thus been initiated by him at the National Gallery and carried on under his direction may well lead to fundamental improvements in methods of conservation. Mr. Rawlins was made C.B.E. in this New Year Honours.

Mr. R. H. G. Thomson

Mr. R. H. G. Thomson, who succeeds Mr. Rawlins at the National Gallery, has been research chemist (senior scientific officer) there since 1955. Born in 1925, he was educated at Charterhouse and Magdalene College, Cambridge, where he obtained a first-class in both parts of the Natural Sciences Tripos. He stayed on to read English, before joining Dr. Charles Singer in the preparation of "A History of Technology" to which $\mathrm{Mr}$. Thomson was himself a contributor. $\mathrm{He}$ is a rapporteur of the Scientific Laboratories Committee of the International Council of Museums, and presented a paper at its Copenhagen meeting in 1959 entitled "Picture Varnishes To-day". This aroused considerable interest, and marked substantial progress in a highly specialized field. It is a major theme for further fundamental research in the National Gallery Laboratory. Mr. Thomson has recently become editor of Studies in Conservation (the journal of the International Institute for Conservation of Historic and Artistic Works) which brings him into touch with a wide circle of investigators, both in Great Britain and abroad. $H_{\Theta}$ is assured of the best wishes of friends and colleagues as he enters upon his new responsibilities.

\section{Geological Society of London Awards}

The following awards for 1960 of the Geological Society of London have been announced: Wollaston Medal to Prof. C. E. Tilley, professor of mineralogy and petrology in the University of Cambridge, for his distinguished researches in mineralogy and petrology especially with relation to metamorphism; Murchison Medal to Dr. A. G. MacGregor, formerly assistant director of H.M. Geological Survey (Scotland), for his work in vulcanology and petrology and problems of the metamorphic rocks in Scotland; Lyell Medal to Dr. Doris Reynolds for her work on the rocks of Northern Ireland and her contributions to petrogenesis ; Prestwich Medal to Sir Vivian Fuchs in recognition of the geological work of the expeditions which he has led in many parts of the world; Wollaston Fund to Mr. M. A. Calver, of H.M. Geological Survey, for his work on faunas of the Coal Measures, especially of the North of England and the Midland Valley of Scotland; Murchison Fund to Dr. D. V. Ager, lecturer in palæontology in the Imperial College of Science and Technology, for his researches on brachiopods and on Mesozoic stratigraphy; a moiety of the Lyell Fund to Dr. J. D. Lawson, lecturer in geology in the University of Birmingham, for his work on the stratigraphy and palæontology of the Ludlow rocks of the Wels Borderland; another moiety of the Lyell Fund to Dr. R. H. Cummings, lecturer in geology in the University of Glasgow, for his researches on the morphology and evolution of the Carboniferous Foraminifera.

\section{British Scientific Attachés}

IN a written reply to a question in the House of Cormmons on February 3 regarding scientific attachés. the Minister of Education, Sir David Eccles, as representing the Minister for Science, said that five scientific attachés are now attached to British embassies abroad. The attaché at Washington is accredited also as scientific adviser (civil) to the High Commissioner in Ottawa. The attaché at Paris is accredited also to Berne and carries out liaison duties in Italy and the Benelux countries. The attaché at Bonn is accredited also to Vienna. The attaché at Stockholm is accredited also to Copenhagen and Oslo, and carries out liaison duties in Finland. In addition, a scientific adviser to the High Commissioner for the United Kingdom is stationed in Delhi. Attachés or advisers are thus accredited to eleven United Kingdom embassies or High Commissioners' offices.

\section{Appointment of Scientific Officers for United States Embassies}

THe U.S. Department of State has announced the appointment of seven additional scientists for its science programme. Three of those appointed are assigned as science officers in New Delhi, Buenos Aires and Rio de Janeiro, four as deputy science officers in London, Stockholm, New Delhi and Tokyo. The men selected are: Earnest Watson, dean of the faculty, California Institute of Technology, as seience officer for New Delhi ; Neal Weber, professor of zoology, Swarthmore College, as science officer for Buenos Aires; Harry W. Wells, chairman, Upper Atmospheric Section, Carnegie Institution of Washington, as science officer for Rio de Janeiro; John B. Bateman, United States Army Chemical Corps, as deputy science officer for London; William Littlowood, United States Navy Hydrographic Office, as deputy science officer for Stockholm; David C. Rife, International Co-operation Administration Adviser to the Government of Thailand, and formerly professor of zoology, Ohio State University, as deputy science officer for New Delhi ; and Marshall Crouch, professor of physies, Case Institute of Technology, as deputy science officer for Tokyo. This is the second series of appointments to be made for the science programme of the Department of State under Wallace R. Brode, science adviser to the Secretary of State. The first appointments assigned science officers to U.S. Embassies in London, Paris, Rome, Bonn, Stockholm and Tokyo (see Nature, 183, $15 ; 1959$ ).

\section{Anglo-American Space Research}

QUEsTIONED in the House of Commons on February 15 regarding the Government's future policy towards space research, the Minister of Aviation, Mr. Duncan Sandys, as representing the Minister for Science, said that the plans for Anglo-American co-operation referred to in the Prime Minister's statement of May 12 and of the Minister of Supply's statement of July 29 were developing satisfactorily and we were proceeding with the preparation of the instruments to be carried in the first satellite. Vertical soundings 